\title{
20
}

\section{RECONFIGURING THE SPACES OF URBAN POLITICS}

\section{Circuits, territories, and territorialization}

\author{
Jennifer Robinson
}

\section{Introduction}

The need to rethink urban politics arises in response to empirical developments in urbanization - such as the vast expansion and fragmentation of urban settlements, the dispersal of urban forms over extended urban regions or corridors, and the expanded role of globalized circuits shaping urbanization (such as policy circuits, networks of urban actors, and investment flows). The provocations for urban studies that have come from the insights of "planetary urbanization" represent an important articulation of this challenge (Brenner and Schmid 2015). But so do the insights developed from international urban development policy, which remind us that most people moving to cities arrive to live in self-constructed housing, often on the peripheries of cities and often facing a life-threatening lack of infrastructure (Mitlin and Satterthwaite 2013). In addition, if those contexts that have not historically informed urban studies serve as starting points for theorization (for shorthand, we might label these as "the Global South"-Parnell and Oldfield 2014), different political issues and formations emerge: the politics of access to and titling of land (Gough and Yankson 2000); the diverse interests of state actors, or state effects, as opposed to "the state" (Eriksen 2017); varied forms of political authority (Beall, Parnell, and Albertyn 2015); violent and ongoing coloniality (Porter and Yiftachel 2018); emergent associational forms of regulation, coordination of everyday life, and mobilization (Diouf and Fredericks 2014).

This sits against a backdrop of theories of urban politics based on an earlier era and on a limited range of contexts (Lauermann 2018). The classic CoxHarvey approach to understanding the urban politics of local economic development focused on municipalities competing for footloose capital (Cox and Mair 1988; Harvey 1989). This flowed from the US context, where locally dependent municipalities and firms configured a certain range of localized 
political formations. Regime theory extended these insights to a nuanced assessment of how actors with different local interests might assemble a growth coalition, often informal, establishing a stable and consistent growth path (Logan and Molotch 1987; Stone 1989). These accounts traveled poorly to Europe (Harding 1994; Ward 1996), and thus wider analyses, such as that of Kantor, Savitch, and Vicari (1997), expanded the range of concerns to consider municipalities in relation to their national political context and the place of cities in relation to a range of international economic relationships. However, even approaches such as these have little purchase in situations where local governance systems are more strongly centralized, local regimes might be more collective and redistributive (Le Galès 2002), or the institutional basis and scope for the operation of local government is weak, highly informalized, or interwoven with traditional/communal forms of land ownership and governance (Parnell and Pieterse 2014; Beall, Parnell, and Albertyn 2015). In addition, a proliferation of transnational actors, such as resource extraction companies (oil, minerals), sovereign investors and development agencies, international NGOs, and actors such as the World Bank, bring a very different configuration to urban politics in many poorer country contexts. Some new starting points are needed for the theorization of urban politics in the 21 st century.

The second era and approach that frames the horizon of thinking in urban politics is that of neoliberalization and, more recently in a similar idiom, financialization (Aalbers 2017). This approach takes us away from the territorially based competitive zero-sum game to attract investment, as articulated in the US-style formulation of urban entrepreneurialism. It also highlights the agency of localized political formations in potentially shaping globalizing circuits of policy, governance, and investment (see Buckley and Hanieh 2014; González et al. 2018). What is relevant for our concerns is the spatial imagination underpinning these analyses of neoliberalization. Peck, Theodore, and Brenner (2009) bring forward the idea of a "syndrome" of neoliberalization in which there is no original or pure neoliberalism, but rather circuits of policy innovation and emergent contradictions shaped by numerous local contexts that constantly generate variegated outcomes, in turn reshaping neoliberalized policy circuits.

To some extent, these analyses have self-consciously addressed a US-EU bias and have attended to the dispersed origins and circuits of neoliberal policies and practices (Peck, Theodore, and Brenner 2009). However, the experiences of poorer contexts are less commonly considered in urban studies, where neoliberalization takes place within often coercive policy circuits (Dobbin, Simmons, and Garrett 2007) in the name of structural adjustment policy or good governance. Furthermore, there are situations where a neoliberal state roll-back has not been possible as state-led institutions have never been present, are differentially present (as a result of colonial inheritance), or are long absent (McDonald 2007). At times, neoliberal innovations have enabled developmental interventions (Ferguson 2010; Parnell and Robinson 2012). In addition, in many contexts, local hybridizations of circulating processes, policy imaginaries, and governance experimentations do not necessarily contribute to the syndrome of "neoliberalism," as the outcomes may be very 
different. In the face of policy dead ends, personal appropriation, and counterhegemonic or even developmental outcomes, scholars need to be able to assess "when is it no longer neoliberalization" (Leitner et al. 2007, 10).

These debates have demonstrated that urban politics is to be located at least partly in the prolific circuits and transnational networks that frame global urbanization. But a wider range of circuits and networks of urban development processes and urban policy could be brought into view. The entwining of global circuits and local economic development politics has formed a key terrain within urban studies - from place competition to world city analysis (Friedmann and Wolff 1982) and global city formation (e.g., Firman 1998). Here I wish to consider the more routine ways in which urban politics is always "more than local," encompassing a range of different transnational circuits (Allen and Cochrane 2014), agendas, actors, and types of relationships. It is with this landscape of urban politics in mind that John Lauermann (2018), in his critical assessment of the US growth coalition model of competitive inter-urban politics, observes that "entrepreneurial cities navigate geographies of inter-urban competition and cooperation. . . The expansion of entrepreneurial practices to multiple governance agendas (in parallel to growth) reflects the formation of extra-territorial political coalitions" (Lauermann 2018, 3, italics added). He suggests that, as a result, "there remains a pressing need to trace how alternative urban politics operate alongside the growth politics of the contemporary entrepreneurial city" (Lauermann 2018, 15). The most important examples of such alternative urban politics have been seen in relation to networks of cities exploring urban bases for climate change action and transnational coalitions of urban actors promoting the UN's urban sustainable development goals (Acuto 2013; Bulkeley 2010; Parnell 2016).

Urban politics therefore needs to be theorized from different starting points than the territorialized politics of competitive local governments, the circuits of capitalist economic globalization, and their intersection. In his foundational analysis, Harvey (1989) already noted the significance of state-led circuits of investment in shaping competitive urban behavior, in which cities compete for military contracts or to secure state projects such as health or education. Kantor, Savitch, and Vicari (1997) expand this to a wider range of national and international circuits that are relevant for city development politics. Moreover, the more recent focus on the prolific policy circulations shaping urban politics (McCann and Ward 2011) invites us to see these circuits themselves as sites of urban politics. This draws attention to the national and supranational formations that shape global urban "reason" (Gonzales et al. 2018): the circuits of policy makers and city governments (Acuto 2013), collective developmental and political initiatives, and municipal networks and associations (Parnell 2016). But it also highlights informal associational connections, including those of trade and migration (Simone 2010), and the complex spatial formations associated with those who direct or switch flows of finance into the built environment, including states, sovereign fund managers, asset managers, or investment advisors (Bassens and van Meeteren 2015; Kanai and Schindler 2019). 
Focusing on the circuits and networks of urban politics calls for more attention to different kinds of actors, as well as the various kinds of associations and relationships that emerge across urban settings and in circuits. Thus, policy mobilizers, development agencies, charitable organizations, think tanks, networking managers, and national, bilateral, and multinational institutions are clearly part of the landscape of the urban political. Earlier theorizations of local economic development politics were closely attentive to the constitution of political interests on an urban scale, exploring the territorial basis for the distinctive interests and motivations of different actors: "local dependence" of businesses, electoral success of governments, the emergent territorially defined interests of growth coalitions in attracting global economic investment or expanding employment, fiscal income streams, or other goals, including acting to secure their interests on regional or national scales (Cox and Mair 1988). An expanded understanding of urban politics, in the wake of analyses of neoliberalization and policy mobilities, points to the need for much more attention to the complex intersections between "locally dependent" actors, "urban" actors whose institutional bases might well be regional or national, and the circulating processes or wider networks framing "urban politics." Here, research on the spatialities of policy mobilities that entrain both circuits and localities (McCann and Ward 2011) as well as the analysis of the politics of international development policy focused on the power relations operative at the interface of international agendas and actors and national/local actors (Dobbin, Simmons, and Garrett 2007) both open up this crucial agenda.

Thus, theoretical insights need to be developed across a much wider array of urban contexts, circuits, and actors than those indexed by the US model or its critical comparative engagement with the European experience. Here, a reformatted urban comparativism can support initiatives to draw a much wider range of urban contexts into consideration (Robinson 2011a; 2015). On the one hand, comparative analyses can be enabled through a focus on circuits that entrain and involve many different urban contexts, often quite promiscuously as policy circulation, or as part of expanding transnational coalitions or municipal networks. Many different urban situations are brought into analytical proximity through their being involved in the same circuits (Porto d'Oliviera 2017; Robinson 2018b; Kanai and Schindler 2019). Attending to a greater diversity of circuits (as processes of urbanization) and the different ways in which relationships among actors are navigated across circuits and localized urban concerns opens up urban political analysis to a wider range of experiences. On the other hand, urban territories can be compared directly. While territorially based comparisons of local governments are notoriously challenging (Kantor and Savitch 2005), the complex, extended, and fragmented nature of contemporary urbanization invites urban political analysis to begin with other types of territories and territorializations. For example, the proliferation of largescale urban developments across many urban contexts makes it possible to directly compare political formations emergent around similar kinds of long-term, multijurisdictional, and transcalar developments (Shatkin 2017; Robinson et al. 2020). Such developments are also frequently interconnected through circuits of policy, 
financial, and material flows which expand opportunities for comparative analysis. On this basis, a diversity of local governments and other urban actors come into view as part of the variation to be explained across many different developments.

Through both these methodological maneuvers, an analytical conversation across quite divergent forms of urban politics becomes possible and can form the basis for developing wider conceptualizations of urban development. We can now consider some examples of how reconfiguring the spaces of urban politics in these ways - in terms of circuits and territories - can substantially expand the repertoire of analyses.

\section{Circuits}

Connections themselves are sites of the urban political, as observed in relation to neoliberalization, which is constituted not only through the variegated formations in (urban) territories but also through international arenas, agencies, and actors. Urban politics happens in the circuits as much as in the territories (Roy and Ong 2011; Acuto 2013). More concretely, the politics of circuits constitutes new "territories" of urban politics, including, for example: networks and associations of municipalities inserting their interests into global policy agendas, such as the SDGs; processes of disseminating the urban agendas of global agencies (such as "rolling out the SDGs"-Kanuri et al. 2016); forming associations on many different topics from climate change to resilience (Bulkley 2010); or more collaborative advocacybased initiatives such as the Cities Alliance, which is discussed later in this chapter. Thus, the power relations and dynamics of globalized circuits and networks are "urban" politics and necessarily involve actors from a wide range of urban contexts.

From the perspective of particular urban contexts, distinctive formations of politics, agents, and interests are often already part of globalized connections and networks-localized formations are intrinsically framed through circulating ideas, practices, and relationships. Thus, "local" actors arrive at policies in the midst of already present "circulating" ideas (Robinson 2016a). Urban agents are territorialized as already networked and connected; networks and global platforms are created as competitive and collaborative formations of (localized) urban actors. Hence, networks become platforms for both constituting and staging urban politics. Networked interactions might be cross-cut with the dynamics of whatever the globally "competitive city" might be concerned with—competing for the personal success of city leaders, visibility in donor circuits, potential economic expansion, or ambitions to seek developmental global change. They might be sites for inter-referencing different urban experiences or carefully learning from fellow practitioners (Roy and Ong 2011; Robinson 2018a). But these networks can equally be sites of invisibility as exclusions and uneven power relations mean that network-generated policy innovations and investments can evade the influence of municipal actors from poorly resourced contexts (Bulkeley 2010).

Important questions for further investigation include: what are the varied politics of global platforms of urban agency? How do transnational dynamics shape 
and in turn get shaped by the interests and activities of urban actors? How is urban politics simultaneously networked and territorialized? Questions also arise about the nature of the "relationalities" that make up networked global urban politics, that is, the interactions and influences achieved in these globalized or networked territories of urban politics. It would be helpful to consider more carefully circuits associated with the largely developmental interventions shaping poorer country contexts, which have received far less attention in urban studies (Porto D'Oliviera 2017). Here, analyses of urban agency need to focus more strongly on the exteriorized nature of the interests and capacities of ostensibly local actors and the diverse types of strategic agency that such actors bring into shaping networks.

We already know well that a certain kind of spectrality, or specular politics, inhabits the zone of local economic development-primarily in the marketing relationships that promote cities through visualizations at odds with their realities; or the silences, deceptions, evasions, or occlusions that have been a central feature of the "models" or stylized best practices that support policy circulations (Wood 2014). In relation to some developmental circuits, such spectralities are effective and impactful. There is scope for both ideas and resources to be mobilized for reasons other than those that are apparent, to be siphoned off or captured for achieving entirely different projects and divergent outcomes than initially envisaged, or for significant decisions to be based on what are known to be inaccurate assumptions.

In Lilongwe, Malawi, an ad hoc city strategy was formulated in 2009 through close cooperation with the City of Johannesburg, which had gained a strong reputation for preparing city strategies (Robinson 2011b; 2018a). The collaboration was initiated and partly supported by the United Cities and Local Governments (UCLG: an international network of municipalities) and partly by the Cities Alliance, an advocacy organization with partners including governments, inter-governmental organizations, and residents' movements. However, the ensuing collaboration was also substantially self-financed by Johannesburg and to some extent by Lilongwe. This exchange attracted my attention, as I was intrigued by the developmental focus of the policy circulation and the slow, engaged person-toperson process of policy learning — quite at odds with the "fast policy" analyses that are currently dominant (Peck and Theodore 2015). The Johannesburg-Lilongwe cooperation to produce a city strategy illuminates the transnational nature of urban politics. In this case, the capacity of Lilongwe municipal employees to act both locally and in the global arena was founded on strong and direct engagement from a series of international actors-Johannesburg municipality, the Cities Alliance, UCLG, the Gates Foundation, JICA, and many other international organizations, donors, and NGOs active in the city (Robinson 2018a).

The production of the city strategy leveraged some much-needed investment in upgrading services in settlements from the Gates Foundation as well as some earlier low-key implementations supported by Johannesburg at the end of the strategic planning process. Once the substantial funding was secured, however, Johannesburg actors were excluded, with informants cynically assuming that this might have been to avoid scrutiny and open up opportunities for personal benefit 
on the part of local actors. While this lengthy, committed developmental process of strategic policy formulation, which stretched over more than three years, had come forward with a number of feasible suggestions for effective development in a well-researched document, the partnership was abandoned. This was also a result of political change and ongoing governance irregularities, which Johannesburg officials felt undermined the possibility for securing "good governance," a prerequisite for their involvement. The value of this work in an administratively challenged context is reflected in the fact that a newly elected mayor was still able to refer to the 2009 City Strategy as a valid future-oriented program of work in 2017 (Robinson 2018a).

We gain some insight into aspects of the transnational dynamics of urban politics in the way in which the city strategy was specularized for personal and institutional benefit. This occurred most obviously in a process of international recognition of the institutional collaboration. Led by a new CEO who had not been involved in the city strategy process, the Lilongwe partners applied for and won a Chinesesponsored local governance award for this work without involving Johannesburg. The city strategy was also "banked" as organizational capital for major transnational actors, including the Cities Alliance and the UCLG. The collaboration was widely cited as a success story (Cities Alliance 2010), part of the ongoing international cityto-city networking programs promoted by the CA and UCLG (UCLG 2013). And the analysis offered in the Lilongwe City Strategy supported decisions in the Cities Alliance to invest together with the Gates Foundation in settlement upgrading in Lilongwe, despite unfavorable assessments of urban governance capacity and integrity (interview, city official and consultant, 2013). Thus, substantial investments in infrastructure and housing in Lilongwe - the core business of international urban development-flowed from spectral/specular and informalized circuits of transnational urban politics.

Specular and informal dynamics of urban politics can therefore be core features of globalized circuits of urban development. It is not enough to see local variegation adding up to yet another case of an already defined global circuit (such as neoliberalization) through assumed processes of policy transfer, planning, or investment calculations. As the Lilongwe City Strategy case illustrates, there are a variety of circuits to consider, with different dynamics. And there is no inevitability as to what a globalizing circuit ends up producing, what the networked politics of urban development might lead to, or through what kinds of relationality transnational urban political processes and outcomes might be shaped.

\section{Territories and territorialization}

Reconfiguring analyses of urban politics can alternatively begin from the diverse territorializations of multiple circuits and urbanization processes. The previous section highlighted circuits and networks as intrinsic elements in any reconfiguration of the spaces of urban politics. In addition, it is important to consider the implications for urban politics of the territorial formations of the urban under planetary 
urbanization as extended, fragmented, sprawling, operational (Brenner and Schmid 2015), and the transnational politics of a "scramble for infrastructure" currently shaping territorial reconfigurations of urbanization as global (Kanai and Schindler 2019). I draw attention here to an approach that can potentially speak to a wide range of emergent territorialized urban formations in the midst of globalized and interconnected but also often dispersed and fragmented urban outcomes: what Ludovic Halbert calls "Transcalar Territorial Networks" (Halbert and Rouanet 2014). In my view, this analysis offers a way forward to revisit the territories of urban politics beyond municipal-based global competition or the entrepreneurial state.

Multiple globalizing circuits shape the future trajectories of urban settlements and, more generally, the extended and fragmented territories that are the outcomes of urbanization processes (Keil 2017; Schmid et al. 2018). An iconic understanding of this sees globalized processes of investment (financialization) producing repeated, seemingly identical urban forms - the serially reproduced satellite city, the repetition of "iconic" architecture, the endlessly borrowed concept or design. However, our research in London suggests that each of these apparently identical buildings requires two to three years of almost weekly meetings between planners and developers to negotiate the details of financing, planning gain, social and hard infrastructure provision, and the detailed design of buildings (Robinson et al. 2020). Actors with varying global reach and different capacities to localize, together with conventions and calculative devices (Christophers 2014) as much as a vast array of legislation and policy are at stake in each negotiated outcome. More generally, I appreciate the Deleuzian formulation in which repetition is always a differentiation, a distinctive "singularity" emergent from the shared/interconnected genetic processes: one of a kind but perhaps also one of a series of outcomes (Jacobs 2012; Robinson 2016b). Thus, while attending to the multiplicity of connections that shape urban outcomes, the repeated instance comes into view (Robinson 2018b).

A repeated instance might be the buildings or large-scale developments in which certain forms of financialized capital are implicated, such as asset management of low-income rental housing products. Or the production of new cities or infrastructure that result from numerous globalizing or translocal circuits-of policy, planning visions, globally competitive economic development strategies, financial investment, or local populations positioning themselves to benefit in some way from planned developments, perhaps long in advance of anything ever being built (van den Broeck 2017; Kanai and Schindler 2019).

In these settings, then, a range of transcalar actors and networks are territorialized in the cooperation, contestation, and creative production of new urban territories. Halbert and Rouanet's concept of transcalar territorial networks takes seriously this complexity of circulations, extensions, and territorializations:

The concept of transcalar territorial networks (TTN) is suggested to explain how resources from multiple horizons are pulled together in a given business 
property development, from a fixed plot of land to capital allocated in distant investment committee boardrooms.

Allen and Cochrane's (2007) conceptualization of "regional assemblages" is also helpful here-different "scales" are flattened into a patchwork of overlapping territorializations of different institutional agency. This opens up new lines of investigation for thinking about urban politics.

Thus, across a range of territories-extended and city-regional configurations, corridors, dispersed fragments of the urban — political formations are assembled out of diverse actors operating with varied reach, capacity, and transcalar competencies. It is important to also layer in the specific regulatory pathways that emerge in urban contexts, perhaps around jurisdictions or governance structures, such as municipalities, metropolitan areas, countries, regions. We can take a cue here from a regulationist idea of a rapport territorial - territorial relations of regulation emergent in different metropolitan contexts:

The territorial relationship generates a contradictory and complex system of dependencies, jurisdictions and rules . . . it consists not only of laws, bylaws and prescriptions, but also of diverse unwritten, implicit rules; as a result it is often barely comprehensible to outsiders - and even so to insiders.

(Schmid 2015, 297)

Thus, the territorial grounds for urban politics could be conceived as emergent territorializations, embracing transcalar territorial networks that constellate around designated urban projects and programs, as well as the complex formations associated with territorialized regulatory assemblages. Rather than competing municipalities and footloose capital, we can acknowledge the emergence of (new) territories on which urban politics emerges, such as large-scale development projects, satellite cities, extensive infrastructural developments, or the transcalar regulatory contexts that establish pathways of development. In these settings, a diverse cast of actors with differently configured interests and concerns emerge, varying from context to context (even within the same city, region, or country).

In this light, the interests and practices of actors may be surprising: "global" developers and architects whose local reputations and relationship inspire more modest goals for developments may be at odds with states whose commitment is to intensify extraction to support their own ambitions. Or developmental state interests in securing an adequate housing supply might be aligned with new processes of globalized investment - financialization or "build to rent" (Robinson and Attuyer 2020; Todes and Robinson 2020). Thus, we need to take seriously the territorial embeddedness of both (global) developers and states.

We also can see how, within the scope of these territorialized formations, openings for effective state agency might not depend on building strong institutionwide agency but could involve having some capacity to shape decision-making 
and negotiations in relation to specific developments. This potentially opens up a significant perspective on questions of African governance, for example, where analysts and development organizations have been perplexed by, and highly critical of, the extensive investments in large-scale urban developments across the continent (Watson 2014; Murray 2017; van Noorloos and Kloosterboer 2018). Here, a determinedly scalar developmental imagination of government/governance could be enriched by a view of transcalar governance and the overlapping circuits (private, developmental, sovereign) shaping African cities. Rather than a good governance agenda focused on improving hierarchical interjurisdictional arrangements (Pieterse, Parnell, and Haysom 2018), close attention to the transcalar territories of urban development might indicate targeted opportunities to improve outcomes (planning gain, application of international law). Improved understanding of the actors, interests, and scope for intervention in these developments could yield stronger public benefit from investments (Turok 2016; Goodfellow 2020).

More generally, the shared features of large-scale developments (multi-jurisdictional, of long duration, with a complexity of interests and shifting governance arrangements) allow them to be fruitfully compared across a very wide range of contexts, potentially contributing to wider theorizations of urban politics (Robinson et al. 2020). In these settings, the nature of the future city is negotiated, and urban politics is revealed. For this, though, it is important not to treat the variety of outcomes as so many different "contexts" making residual contributions to wider circuits (van Loon, Oosterlynck, and Aalbers 2018). Rather, comparative analysis of the (transcalar) territories (Halbert and Rouanet 2014) of largescale urban developments could build new theoretical insights across a diversity of urban politics rather than framing these as "variegated" cases of wider processes or circuits.

Gavin Shatkin's $(2016 ; 2017)$ comparative study of three large-scale urban development projects in Asia is especially helpful in this regard. He insists that these cases can be treated as starting points for new theoretical analyses, emergent from Asian experiences and appropriate to contemporary global urbanization. In his view, theorizations of urban politics need to encompass "state capitalism," as well as the land grabs characteristic of peremptory states, and the often exuberant and informalized political contestation associated with democratic but poorly capacitated states. $\mathrm{He}$ summarizes his analytical insights in relation to the dimensions of more or less autonomy of state land managers, and more or less state control of land markets.

Starting from this theorization inspired by the Asian context, a closer focus emerges on the interests of the state itself in urban development (Shen, Luo, and Wu 2020). This has been occluded in favor of a focus on the politics of financialization, neoliberalization, and the role of global developers (Aalbers 2017; Robinson and Attuyer 2020). In a recent comparative research project (London-JohannesburgShanghai), ${ }^{1}$ we focused on three large-scale development projects and identified significant territorializations of urban politics at the scale of the "project" (Pinson 2009). Our study expands Shatkin's insights from the Asian context, bringing into 
view a wider diversity of ways in which states and other urban actors manage land value extraction to enable new urban developments. Across the three cases, we identified a common state interest in extracting rents from different aspects of the newly constructed urban environment, at least partly in order to pay for the development itself (Robinson et al. 2020). However, rather than interpreting these as reflecting variegated forms of financialization or neoliberalization, our comparative analysis identified three business models (distinctive configurations of governance and financing arrangements) with diverse practices for generating and capturing urban value through urban development (Theurillat 2015). On this basis, we were able to explore the implications of different business models for the outcomes in each case.

Our cases highlight the difference made by these business models. In London, direct value capture on a one-off basis at the point and time of construction (through negotiated planning gain) put great pressure on built form to generate income, leading to dense and high-rise developments with low levels of affordable housing. A more metropolitan scale and dynamic property tax system in Johannesburg enabled a redistributive emphasis on providing well-located, low-income housing. And the even wider accounting of the potential returns on urban development through taxation of new enterprises and generalized economic growth supported transformational economic policies of industrial upgrading in Shanghai. The scope to understand the interests and roles of different actors, and to inform critical analysis of different business models, comes into view through comparative analysis. Thus, state actors might be motivated by electoral concerns to promote redistributive outcomes (Harrison et al. 2019), or by securing consent for (or at least compliance with) the processes of removal and development (Wang and Wu 2019), maximizing income streams (Robinson and Attuyer 2020), or effectively managing developmental growth agendas across complex institutional spaces, in part through market mechanisms (Shen, Luo, and Wu 2020; Wu 2020).

As international actors ranging from sovereign wealth funds to transnational private firms or developmental agencies turn to the urban built environment to realize both profit and potential public benefit, including in some of the poorest urban contexts (Turok 2016), it is important to be aware of the range of ways in which urbanization can be secured, governed, and financed. The business models of large-scale urban developments are diverse and the role and interests of different actors involved in securing urban developments are highly specific, even as transnational processes and actors are key in most large-scale urban developments. While enhancing land value as well as securing other value streams through development is often the foundation for financing urban development, the different ways of mobilizing resources and realizing value to enable the development make a significant difference to outcomes-in terms of the physical form of the development, the types of activities supported, and the relative distribution of benefits to different agents of development and to the wider society (Robinson et al. 2020). 


\section{Conclusion: reconfiguring urban politics}

This chapter has explored the rich potential to reconfigure the spaces of urban politics. This involves expanding the territories from which urban politics might be theorized and encouraging urban scholars to take into account a much richer array of actors and more varied explanations for their actions and interests. I have suggested that a diversity of transnational networks and circuits represent new territories of urban politics, which convene a range of different kinds of political interests and dynamic relationships involving urban actors from across the globe. In addition, by starting with the fragmented and dispersed territories that characterize contemporary processes of (planetary) urbanization, such as large-scale urban developments, direct comparisons can be drawn across highly diverse urban settings, expanding and enriching insights into the interests of urban actors and the nature and outcomes of urban development politics. On the basis of such a reformatted comparative analysis, places like London can become destinations for theory from elsewhere, for example, learning from analyses of state interests in land development from Asia. More generally, in a world where all cities might be thought of as "ordinary" and thus assumed to contribute to wider theorizations (Robinson 2006), understandings of the spaces and nature of urban politics can be reconfigured through comparative analysis of the diverse territories and circuits of global urbanization.

\section{Note}

1 With Phil Harrison and Fulong Wu, I acknowledge funding from the ESRC for an Urban Transformations grant ES/N006070/1, "Governing the Future City: A comparative analysis of governance innovations in large-scale urban developments in Shanghai, London, Johannesburg."

\section{References}

Aalbers, M. B. 2017. "The Variegated Financialization of Housing." International Journal of Urban and Regional Research 41 (4): 542-554.

Acuto, M. 2013. “The New Climate Leaders?” Review of International Studies 39 (4): 835-857. Allen, J., and A. Cochrane. 2007. "Beyond the Territorial Fix: Regional Assemblages, Politics and Power." Regional Studies 41: 1161-1175.

Allen, J., and A. Cochrane. 2014. "The Urban Unbound: London's Politics and the 2012 Olympic Games." International Journal of Urban and Regional Research 38: 1609-1624.

Bassens, D., and M. van Meeteren. 2015. "World Cities under Conditions of Financialized Globalization: Towards an Augmented World City Hypothesis." Progress in Human Geography 39 (6): 752-775.

Beall, J., S. Parnell, and C. Albertyn. 2015. "Elite Compacts in Africa: The Role of AreaBased Management in the New Governmentality of the Durban City-region." International Journal of Urban and Regional Research 39 (2): 390-406.

Brenner, N., and C. Schmid. 2015. "Towards a New Epistemology of the Urban?" City 19 (2-3): 151-182. 
Buckley, M., and A. Hanieh. 2014. "Diversification by Urbanization: Tracing the PropertyFinance Nexus in Dubai and the Gulf. International Journal of Urban and Regional Research 38 (1): 155-175.

Bulkeley, H. 2010. "Cities and the Governing of Climate Change." Annual Review of Environment and Resources 35: 229-253.

Christophers, B. 2014. "Wild Dragons in the City: Urban Political Economy, Affordable Housing Development and the Performative World-making of Economic Models." International Journal of Urban and Regional Research 38 (1): 79-97.

Cities Alliance. 2010. Cities Alliance in Action: Johannesburg-Lilongwe Partnership Leads to a Robust City Development Strategy. www.citiesalliance.org/resources/knowledge/ cities-alliance-knowledge/cities-alliance-action-johannesburg-lilongwe.

Cox, K., and A. Mair. 1988. "Locality and Community in the Politics of Local Economic Development." Annals of the Association of American Geographers 78 (2): 307-325.

Diouf, M., and R. Fredericks. 2014. The Arts of Citizenship in African Cities: Infrastructures and Spaces of Belonging. London: Palgrave MacMillan.

Dobbin, F., B. Simmons, and G. Garrett. 2007. "The Global Diffusion of Public Policies: Social Construction, Coercion, Competition, or Learning?" Annual Review of Sociology 33: 449-472.

Eriksen, S. 2017. "State Effects and the Effects of State Building: Institution Building and the Formation of State-Centred Societies." Third World Quarterly 38 (4): 771-786.

Ferguson, J. 2010. “The Uses of Neoliberalism.” Antipode 41: 166-184.

Firman, T. 1998. "The Restructuring of Jakarta Metropolitan Area: A 'Global City' in Asia.” Cities 15 (4): 229-243.

Friedmann, J., and G. Wolff. 1982. "World City Formation: An Agenda for Research and Action." International Journal of Urban and Regional Research 6: 309-344.

González, S., S. Oosterlynck, R. Ribera-Fumaz, and U. Rossi. 2018. "Locating the Global Financial Crisis: Variegated Neoliberalization in Four European Cities." Territory, Politics, Governance 6 (4): 468-488.

Goodfellow, T. 2020. "Finance, Infrastructure and Urban Capital: The Political Economy of African 'Gap-Filling'." Review of African Political Economy. doi: 10.1080/03056244.2020.1722088.

Gough, K., and P. Yankson. 2000. "Land Markets in African Cities: The Case of Peri-Urban Accra, Ghana." Urban Studies 37 (13): 2485-2500.

Halbert, L., and H. Rouanet. 2014. "Filtering Risk Away: Global Finance Capital, Transcalar Territorial Networks and the (Un)Making of City-Regions: An Analysis of Business Property Development in Bangalore, India." Regional Studies 48 (3): 471-484.

Harding, A. 1994. "Urban Regimes and Growth Machines: Towards a Cross-National Research Agenda." Urban Affairs Quarterly 29 (3): 356-382.

Harrison, P., M. Rubin, A. Appelbaum, and R. Dittgen. 2019. "Corridors of Freedom: Analyzing Johannesburg's Ambitious Inclusionary Transit-Oriented Development.” Journal of Planning Education and Research 39 (4): 456-468. doi: 10.1177/0739456X19870312.

Harvey, D. 1989. "From Managerialism to Entrepreneurialism: The Transformation in Urban Governance in Late Capitalism." Geografiska Annaler. Series B, Human Geography 71 (1): 3-17.

Jacobs, J. 2012. "Commentary: Comparing Comparative Urbanisms." Urban Geography 33 (6): 904-914.

Kanai, J. M., and S. Schindler. 2019. "Peri-Urban Promises of Connectivity: Linking Project-Led Polycentrism to the Infrastructure Scramble." Environment and Planning A: Economy and Space 51 (2): 302-322. 
Kantor, P., and H. V. Savitch. 2005. "How to Study Comparative Urban Development Politics: A Research Note." International Journal of Urban and Regional Research 29 (1): 135-151.

Kantor, P., H. V. Savitch, and S. Vicari. 1997. "The Political Economy of Urban Regimes: A Comparative Perspective." Urban Affairs Review 32 (3): 348-377.

Kanuri, C., A. Revi, A. Espey, and H. Kuhle. 2016. "Getting Started with the SDGs in Cities." Sustainable Development Solutions Network. Accessed November 24, 2020. https:// resources.unsdsn.org/getting-started-with-the-sdgs-in-cities.

Keil, R. 2017. Suburban Planet: Making the World Urban from the Outside In. Cambridge: Polity.

Lauermann, J. 2018. "Municipal Statecraft: Revisiting the Geographies of the Entrepreneurial City." Progress in Human Geography 42 (2): 205-224.

Le Galès, P. 2002. European Cities: Social Conflicts and Governance. Oxford: Oxford University Press.

Leitner, H., E. Sheppard, K. Sziarto, and A. Maringanti. 2007. "Contesting Urban Futures: Decentering Neoliberalism.” In Contesting Neoliberalism, edited by H. Leitner, J. Peck, and E. Sheppard, 1-25. New York: Guilford.

Logan, J., and H. Molotch. 1987. Urban Fortunes: The Political Economy of Place. Berkeley: University of California Press.

McCann, E., and K. Ward. 2011. Mobile Urbanisms. Minneapolis: University of Minnesota Press.

McDonald, D. 2007. World City Syndrome: Neoliberalism and Inequality in Cape Town. New York: Routledge.

Mitlin, D., and D. Satterthwaite, eds. 2013. Urban Poverty in the Global South: Scale and Nature. London: Routledge.

Murray, M. 2017. The Urbanism of Exception: The Dynamics of Global City Building in the Twenty-First Century. Cambridge: Cambridge University Press.

Parnell, S. 2016. "Defining a Global Urban Development Agenda." World Development 78: $529-540$.

Parnell, S., and S. Oldfield, eds. 2014. Handbook for Cities of the Global South. London: Routledge.

Parnell, S., and E. Pieterse, eds. 2014. Africa's Urban Revolution. London and New York: Zed Books.

Parnell, S., and J. Robinson. 2012. "(Re)theorising Cities from the Global South: Looking beyond Neoliberalism.” Urban Geography 33 (4): 593-617.

Peck, J., and N. Theodore. 2015. Fast Policy: Experimental Statecraft at the Thresholds of Neoliberalism. Minneapolis: Minnesota University Press.

Peck, J., N. Theodore, and N. Brenner. 2009. "Neoliberal Urbanism: Models, Moments, Mutations." SAIS Review XXIX (1): 49-66.

Pieterse, E., S. Parnell, and G. Haysom. 2018. "African Dreams: Locating Urban Infrastructure in the 2030 Sustainable Developmental Agenda." Area Development and Policy 3 (2): 149-169.

Pinson, G. 2009. Gouverner la ville par projet: Urbanisme et gouvernance des villes européenes. Paris: Presses de la fondation national des sciences politiques.

Porter, L., and O. Yiftachel. 2018. "Urbanizing Settler-Colonial Studies: Introduction to the Special Issue." Settler Colonial Studies 9 (2): 177-186. doi: 10.1080/2201473X.2017.1409394.

Porto de Oliviera, O. 2017. International Policy Diffusion and Participatory Budgeting. Basingstoke, UK: Palgrave Macmillan.

Robinson, J. 2006. Ordinary Cities. London: Routledge. 
Robinson, J. 2011a. "Cities in a World of Cities: The Comparative Gesture." International Journal of Urban and Regional Research 35: 1-23.

Robinson, J. 2011b. "The Spaces of Circulating Knowledge: City Strategies and Global Urban Governmentality." In Mobile Urbanism: Cities and Policymaking in the Global Age, edited by E. McCann and K. Ward, 15-40. Minneapolis: University of Minnesota Press.

Robinson, J. 2015. "Comparative Urbanism: New Geographies and Cultures of Theorizing the Urban." International Journal of Urban and Regional Research 40 (1): 219-227.

Robinson, J. 2016a. “'Arriving At' Urban Policies: The Topological Spaces of Urban Policy Mobility." International Journal of Urban and Regional Research 39 (4): 1468-2427.

Robinson, J. 2016b. "Thinking Cities through Elsewhere: Comparative Tactics for a More Global Urban Studies.” Progress in Human Geography 40 (1): 3-29.

Robinson, J. 2018a. "The Politics of the (Global) Urban: City Strategies as Repeated Instances." In The City as a Global Actor, edited by S. Oosterlynck, D. Bassens, L. Beeckmans, B. DeRudder, L. Braeckmans, and B. Segaert, 100-131. London: Routledge.

Robinson, J. 2018b. "Policy Mobilities as Comparison: Urbanization Processes, Repeated Instances, Topologies." Revista de Administração Pública 52 (2): 221-243. doi: 10.1590/0034-761220180126.

Robinson, J., and K. Attuyer. 2020. "Extracting Value, London Style: Revisiting the Role of the State in Urban Development." International Journal of Urban and Regional Research. doi: 10.1111/1468-2427.12962.

Robinson, J., P. Harrison, J. Shen, and F. Wu. 2020. "Financing Urban Development, Three Business Models: Johannesburg, Shanghai and London.” Progress in Planning. doi: 10.1016/j.progress.2020.100513.

Roy, A., and A. Ong. 2011. Worlding Cities. Oxford: Wiley-Blackwell.

Schmid, C. 2015. "Specificity and Urbanization: A Theoretical Outlook." In The Inevitable Specificity of Cities, edited by C. Diener, J. Herzog, M. Meili, P. de Meuron, M. Herz, C. Schmid, and M. Topalovic, 287-307. Zurich: Lars Müller Publishers.

Schmid, C., O. Karaman, N. Hanakata, P. Kallenberger, A. Kockelkorn, L. Sawyer, M. Streule, and K. P. Wong. 2018. "Towards New Vocabularies of Urbanization Processes: A Comparative Approach.” Urban Studies 55 (1): 19-52.

Shatkin, G. 2016. "The Real Estate Turn in Policy and Planning: Land Monetization and the Political Economy of Peri-Urbanization in Asia." Cities 53: 141-149.

Shatkin, M. 2017. Cities for Profit: The Real Estate Turn in Asia's Urban Politics. Ithaca: Cornell University Press.

Shen, J., X. Luo, and F. Wu. 2020. "Assembling Mega-Urban Projects Through StateGuided Governance Innovation: The Development of Lingang in Shanghai." Regional Studies. doi: 10.1080/00343404.2020.1762853.

Simone, A. 2010. City Life: From Dakar to Jakarta. London: Routledge.

Stone, C. 1989. Regime Politics: Governing Atlanta, 1946-1988. Lawrence: Kansas University Press.

Theurillat, T. 2015. "The Creation of Urban Value in China: The Case of the Modernization of Qujing City in Yunnan." Working Paper 1, MAPS, University of Neuchâtel. Accessed June 3, 2020. www.unine.ch/files/live/sites/maps/files/shared/documents/ wp/WP-1_2015_Theurillat.pdf.

Todes, A., and J. Robinson. 2020. "Re-Directing Developers: New Models of Rental Housing Development to Re-Shape the Post-Apartheid City? Environment and Planning A: Economy and Space 52 (2): 297-317.

Turok, I. 2016. "Getting Urbanization to Work in Africa: The Role of the Urban LandInfrastructure-Finance Nexus.” Area Development and Policy 1 (1): 30-47. 
UCLG. 2013. Peer Learning: UCLG Mentoring Stories, Johannesburg and Lilongwe, 2008-2012. Accessed March 6, 2018. https://issuu.com/uclgcglu/docs/jb_lilongwestory.

Van den Broeck, J. 2017. “We Are Analogue in a Digital World': An Anthropological Exploration of Ontologies and Uncertainties around the Proposed Konza Techno City Near Nairobi, Kenya." Critical African Studies 9 (2): 210-225.

Van Loon, J., S. Oosterlynck, and M. Aalbers. 2018. "Governing Urban Development in the Low Countries: From Managerialism to Entrepreneurialism and Financialization." European Urban and Regional Studies 26 (4): 400-418.

Van Noorloos, F., and M. Kloosterboer. 2018. "Africa's New Cities: The Contested Future of Urbanisation.” Urban Studies 55 (6): 1223-1241.

Wang, Z., and F. Wu. 2019. "In-Situ Marginalisation: Social Impact of Chinese MegaProjects.” Antipode 51: 1640-1663. doi: 10.1111/anti.12560.

Ward, K. 1996. "Rereading Urban Regime Theory: A Sympathetic Critique." Geoforum 27 (4): 427-438.

Watson, V. 2014. "African Urban Fantasies: Dreams or Nightmares?" Environment and Urbanization 26 (1): 215-231.

Wood, A., 2014. "Moving Policy: Global and Local Characters Circulating Bus Rapid Transit through South African Cities." Urban Geography 35 (8): 1238-1254.

Wu, F. 2020. "The State Acts through the Market: 'State Entrepreneurialism' beyond Varieties of Urban Entrepreneurialism." Dialogues in Human Geography. Advance online publication. doi: 10.1177/2043820620921034. 